\title{
Impact of Iron Supplementation on Anemia During Pregnancy
}

\author{
Taru Agarwal*, G.K. Kochar** and Sonali Goel*** \\ Department of Home Science, Kurukshetra University, Kurukshetra, Haryana, India \\ E-mail: *<taruagarwal2003@yahoo.com>**<kochargk@yahoo.com>, \\ ***<Sonaligoel22@yahoo.co.in
}

KEYWORDS Pregnancy; anemia; hemoglobin; iron rich preparation

\begin{abstract}
Pregnancy is a time in which the risk for developing iron deficiency anemia is highest, due to increase of iron requirement. Maternal nutrition is often considered as an important regulator of human fetal growth. Objectives: To study the impact of iron supplementation on anemia during pregnancy. Salty rice flakes preparation was prepared. Sixty volunteered pregnant women in their III trimester of pregnancy, who were visiting L.N.J.P. hospital regularly, undergo experimental trial. Ten non anemic pregnant women were included in control group. A questionnaire regarding general information was filled up. $\mathrm{Hb}$ was measured by Sahli's technique. ' $\mathrm{t}$ ' test was applied to study the effect of supplementation. All the subjects were showing symptoms of anemia but signs were not same. Majority $(90 \%)$ were showing paleness of eyes. Hb values of group B and C were more than the control group A and were found significant in comparison with group A. Thus iron supplementation in both forms (Tablet as well as Food) is helpful in managing anemia during pregnancy.
\end{abstract}

\section{INTRODUCTION}

In Anemia, there is an inadequate supply of red blood cells which results decrease in the oxygen carrying capacity of the blood to the tissues and organs. WHO has defined anemia as a condition in which hemoglobin content of blood is lower than normal $(11 \mathrm{~g} / \mathrm{dl}$ of blood $)$ as a result of deficiency of one or more essential nutrients," (Sulbha, 1999). Iron deficiency probably is the most common form of nutritional deficiency in both developing and developed countries (Sarwate et al., 1994).

Iron deficiency is highest in population segments that are at peak rates of growth, namely, infants, young children and pregnant women. Pregnancy is a time in which the risk for developing iron deficiency anemia is highest because iron requirements substantially increases because of the expansion of blood volume and demand of the growing fetus. Strong evidences are supporting that in many underdeveloped and developing countries, Iron Deficiency Anemia (IDA) during pregnancy in women is commonly prevalent. Studies have shown that IDA is prevalent in at least 40 to 60 per cent of the expectant mothers in the developing countries including India (Raman, 1986).

In India, most of the population is vegetarian and foodstuffs of Indian diet contain significant amount of phytates, phosphates, oxalates and tannates, which form insoluble complexes with iron and reduce iron absorption. Iron supplementation under trial conditions prevents or corrects the anemia.

Only few studies are available to show the co relation of vegetarian diet and its effect on low hemoglobin level on anemic pregnant women. Supplementation of iron, in the form of food is more helpful if considered in National Nutrition Prophylaxis Programme (Sarwate et al.,1994).

Therefore, the present study was undertaken to find out the impact of supplementation of iron rich food preparations as well as iron tablets on anemic conditions of vegetarian women during third trimester of pregnancy.

\section{MATERIAL AND METHODS}

Commonly consumed and liked salty rice flacks preparation was prepared by mixing $25 \mathrm{~g}$ of ground nut, $25 \mathrm{~g}$ of roasted Bengal gram and 5 $\mathrm{g}$ of mango powder in $50 \mathrm{~g}$ of fried rice flakes (Table 1). Iron content of each ingredient used in the preparation of salty rice flakes preparation was determined by Wong's spectrophotometer method (Wong, 1928).

Table 1: Ingredients and iron content of rice flakes namkeen/serving.

\begin{tabular}{lcc}
\hline Ingredients & Weight $(\mathrm{g})$ & Iron content $(\mathrm{mg})$ \\
\hline Rice flakes & 50 & 11 \\
Ground Nut & 25 & .62 \\
Roasted Bengal Gram & 25 & 2.25 \\
Mango Powder & 5 & 2.0 \\
\hline Total & 10 & 15.87 \\
\hline
\end{tabular}


Hundred rural pregnant women of lowincome group aged from 18-27 years and who were visiting L.N.J.P. civil hospital regularly, in their III trimester of pregnancy of Kurukshetra, were purposively recruited for this study. The $\mathrm{Hb}$ of these subjects was measured by Sahli's method.

Among studied subjects, sixty anemic women who volunteered for participating in feeding trials were selected for experimental trail. These subjects were classified in to experimental groups -B \& C, thirty subjects in each group. Among the selected subjects, ten non- anemic women were designated under control group (A). General information and socio-economic status of each subject was collected through questionnaire cum interview method on pre tested and structured questionnaire.

In addition to the daily diet, to the each subjects of the group -I, supplement of iron tablets in the form of dried ferrous sulfate (335 $\mathrm{mg}$ ) containing approximately $100 \mathrm{mg}$ of ferrous iron was given and to the each subjects of group II, iron rich food preparation containing $16 \mathrm{mg}$ iron along with iron tablets mentioned above was given. After 90 days of feeding trail, the impact of supplementation on the expectant mothers was assessed by measuring $\mathrm{Hb}$ of each subject.

\section{RESULTS}

Table 1 shows the iron content of iron rich recipe. Rice Flakes Namkeen was containing approximately $16 \mathrm{mg}$ of iron. Table 2 illustrates that majority of the subjects $(50 \%)$ were between 21-24 years of age. The socioeconomic information of pregnant women revealed that good number of the respondents $(58.33 \%)$ were belonging to nuclear families. About half of the studied families had their monthly earning between Rs 2100-4500. The subjects studied up to primary and middle levels were about 20 per cent $(33.33 \%)$ in each group. Few subjects (13.33 per cent) were educated up to Matric. There was also little number of subjects (16.6\%) who was illiterate whereas 3.33 per cent of the subjects were only able to read.

Table 3 presents the visibility of the symptoms of anemia was noticed in all the studied subjects but the symptoms were not same in all the respondents. Paleness of eyes was viewed in highest number of the subjects (90 per cent). However, the Scarlet tongue, paleness of skin and nails was glimpsed in 66.66, 80 and 88.33 per cent of subjects respectively. About half the subjects were having symptoms of angular stomatittis (56.66\%). In few subjects, pigmented skin $(20 \%)$ and raw tongue $(33.33 \%)$ also floated up. A majority of subjects complained for tiredness' $(56.66 \%)$. Problem of anorexia was faced by about 50 per cent of the subjects $(55 \%)$.

Table 2: General information of the studied subjects

\begin{tabular}{|c|c|c|}
\hline$\overline{\text { Characteristics Details }}$ & $\begin{array}{l}\text { Number } \\
\text { of subjects }\end{array}$ & $\%$ \\
\hline \multicolumn{3}{|l|}{ Type of Family } \\
\hline Nuclear & 35 & 58.33 \\
\hline Joint & 25 & 41.66 \\
\hline \multicolumn{3}{|c|}{ Monthly Income of Family (Rs) } \\
\hline Up to 2100 & 20 & 33.33 \\
\hline $2100-4500$ & 30 & 50.00 \\
\hline $4500-7000$ & 10 & 16.66 \\
\hline \multicolumn{3}{|c|}{ Age of Respondents (Years) } \\
\hline $18-21$ & 20 & 33.33 \\
\hline $21-24$ & 30 & 50.00 \\
\hline $24-27$ & 10 & 16.66 \\
\hline \multicolumn{3}{|l|}{ Educational Status } \\
\hline Illiterate & 10 & 16.66 \\
\hline Can read only & 2 & 3.33 \\
\hline Primary & 20 & 33.33 \\
\hline Middle & 20 & 33.33 \\
\hline Matric & 8 & 13.33 \\
\hline \multicolumn{3}{|c|}{ Table 3: Symptoms of anemia observed in subjec } \\
\hline $\begin{array}{l}\text { Clinical status } \\
\text { and symptoms }\end{array}$ & $\begin{array}{l}\text { Number } \\
\text { of subjects }\end{array}$ & $\%$ \\
\hline Eye $\quad-$ pale & 54 & 90.00 \\
\hline \multirow{2}{*}{$\begin{array}{c}\text { Tongue - scarlet } \\
\text { Raw }\end{array}$} & 40 & 66.66 \\
\hline & 20 & 33.33 \\
\hline \multirow{6}{*}{$\begin{array}{l}\text { Angular stomatit } \\
\text { Paleness of nails } \\
\text { Being tired soon } \\
\text { Anorexia }\end{array}$} & 48 & 80.00 \\
\hline & 12 & 20.00 \\
\hline & 34 & 56.66 \\
\hline & 53 & 88.33 \\
\hline & 34 & 56.66 \\
\hline & 33 & 55.00 \\
\hline
\end{tabular}

Table 4 shows that the $\mathrm{Hb}$ level of subjects of experimental group $\mathrm{B}$ and $\mathrm{C}$ increased on giving Iron supplementation in the form of $\mathrm{Fe}$ tablet as well as iron rich food in comparison to the subjects of group A. This difference was statistically significant at $5 \%$ level. Earlier reports (Mahomed, 2000; Moulessehoul et al., 2004) also showed the impact of iron supplementation in pregnancy and found that the supplementation prevent the fall in hemoglobin during pregnancy.Analysis of data further indicated that increase in the $\mathrm{Hb}$ level of group $\mathrm{C}$ was more after giving iron rich food along with Fe tablet than that of subjects of group B taking only $\mathrm{Fe}$ tablet. But this difference was found apparent. 
Table 4: Hemoglobin of subjects before and after the trial

\begin{tabular}{lcccc}
\hline Groups & $N$ & $\begin{array}{c}\mathrm{Hb} \\
\text { initial }\end{array}$ & $\begin{array}{c}\text { Hb- } \\
\text { final }\end{array}$ & $\begin{array}{c}\text { Groups } \\
\text { com- } \\
\text { pared }\end{array}$ \\
\hline
\end{tabular}

\begin{tabular}{llllll}
\hline Control & 10 & $11.15 \pm 0.21$ & $10.58 \pm 0.76$ & A vs B & $4.41^{*}$
\end{tabular}

(A)

Iron Tab. $30 \quad 8.1 \pm 1.48 \quad 8.95 \pm 1.54$ A vs C $3.41^{*}$

Supple-

mented

(B)

Iron Rich $\quad 30 \quad 8.0 \pm 1.36 \quad 9.36 \pm 1.45 \quad \mathrm{~B}$ vs C 1.06

food

supple-

mented

(C)

* Significant at $5 \%$ level

The result of the present study are also in agreement with the findings of Rusia et al. (1999) who reported that iron supplementation being given to pregnant women has been effective in improving hemoglobin level.

\section{CONCLUSION}

In order to assess the impact of iron tablet and salty rice flakes preparation supplementation on anemic condition of women in their III trimester of pregnancy, 60 anemic women were selected for feeding trial and divided into two groups $-\mathrm{B}$ and C.10 women who were non anemic were selected for control group- A. The group B and C were experimental and to B group, supplement of iron tablets in the form of ferrous sulfate (335 $\mathrm{mg}$ ) and to $\mathrm{C}$ group iron rich food preparation (16mg iron) along with same iron tablets in addition to the daily diet were given daily for 90 days.

The results concluded that there is a signi- ficant difference in anemic condition of group iron tablet supplemented group (B) and iron Rich Food Supplemented group (C) as compared to control group (A). More improvement in hemoglobin values of group $\mathrm{C}$ was also noticed in comparison to group B but statistically the difference was found non significant. It is recommended that both kind of supplementation of iron are helpful in managing anemia among pregnant women.

\section{ACKNOWLEDGEMENT}

I owe a never ending debt of gratitude to my adored and worshipful God for His grace in the completion of this study. I grateful acknowledge to Mr. Avatar Singh, Sr. Lab. Technician. L.N.J.P. Civil Hospital, Kurukshetra.

\section{REFERENCES}

Mahomed, K.2000. "Iron supplementation in pregnancy." Cochrane Database Syst Rev., (2) CD000117.

Moulessehoul, S., A. Demmouche, Y. Chafi and M. Benali. 2004. "Effect of Iron Supplementation among Pregnant Women at Mother -and-Baby clinic of Sidi Bel Abbes, West Algeria." Sante, 14: 21-29

Raman, L. 1986. "Risk care approach to anemia in pregnancy in an urban slum population," ICMR Bulletin, 7(10): 7-8.

Rusia,U., S. Gupta, N. Agarwal, K. C. Singh, M. Sikka and N. Madan. 1999. "Efficacy of the New Program of Iron Supplementation in Pregnancy in India." Indian Mediars Centre, 17(4): 87-91.

Sarwate, Nandani, S. Kamlesh, and S. Singh. 1994. "Impact of supplementing indigenous sweet (Ladoo) on Hemoglobin level of Anemic Children." Ind. J. Nutr. Diet., 31: 262.

Sulbha V.: 1999, "Anemia and Pregnancy." J. Diet Nut., 26(6): $5-27$

Wong, S.Y. 1928. "Calorimetric determination of iron and hemoglobin in blood." J. Bio Chem., 77: 409. 